\title{
PERSPECTIVAS DA ECONOMIA SOLIDÁRIA EM MICRORREGIÕES DO OESTE CATARINENSE
}

\section{PERSPECTIVES OF SOLIDARITY ECONOMY IN MICROREGIONS OF WEST SANTA CATARINA}

\author{
Luiz Victor Pittella Siqueira \\ Universidade Federal da Fronteira Sul - Chapecó - SC - Brasil \\ Dunia Comerlatto \\ Universidade Comunitária da Região de Chapecó - Chapecó - SC - Brasil \\ Jesica Mai \\ Prefeitura Municipal de Águas de Chapecó - Águas de Chapecó - SC - Brasil
}

\begin{abstract}
Resumo: Como campo de trabalho, a Economia Solidária é alternativa diferenciada para construir possibilidades de geração de renda e inclusão sócio-produtiva. Projetam-se os empreendimentos econômicos solidários como capazes de gerar desenvolvimento com maior valorização do ser humano e do meio ambiente. Este artigo traz uma discussão sobre Economia Solidária no oeste catarinense, com o objetivo de compreender as perspectivas das suas ações, considerando as características de gestão, instituições apoiadoras e desafios políticos operacionais. Apoia-se no método misto de pesquisa, uma vez que permite recortar e mesclar dados de caráter quantitativo e qualitativo, proporcionando maior legitimidade e aperfeiçoamento na compreensão das categorias e variáveis que se expressam em torno do objeto estudado. Utilizou-se da pesquisa de campo na abrangência das microrregiões da Associação dos Municípios do Extremo Oeste de Santa Catarina-Ameosc e Associação dos Municípios do Oeste de Santa Catarina-Amosc. Na Ameosc foram pesquisados Empreendimentos Econômicos Solidários-EES e instituições apoiadoras de suas ações e na Amosc, apenas essas instituições. Para a pesquisa de campo, com os sujeitos selecionados (representantes dos empreendimentos e lideranças), utilizou-se da aplicação de formulário e realização de entrevistas. A partir dos dados coletados sob a formalização jurídica, destaca-se a forma de associação, como a mais usual entre os empreendimentos nas duas microrregiões. Entre as atividades produtivas dos empreendimentos, destaca-se a produção de alimentos e de artesanatos. O modo autogestionário adotado nos empreendimentos pesquisados tem propiciado, em especial, a integração entre sócios e a geração complementar de renda. Não obstante, há dificuldades a serem superadas: baixa escolaridade dos trabalhadores; diversificação e diferenciação dos produtos; e, pouco envolvimento dos associados na
\end{abstract}


gestão do empreendimento. Além disso, a dinâmica de gestão dos EES também possui dificuldades político-operacionais a serem superadas: limitada abrangência comercial e participação em redes; formalização jurídica adequada para ampliar possibilidades comerciais e de investimentos. As instituições de apoio aos empreendimentos solidários são diversas no âmbito da esfera governamental e não governamental, proporcionando acessos à infraestrutura e orientações técnico-gerenciais e de qualificação profissional e política. Os EES, como unidades de trabalho sócioprodutivo, são capazes de gerar processos de participação, auto-gestão e de desenvolvimento regional mais igualitário e sustentável.

Palavras-chave: Economia solidária. Inclusão sócio-produtiva. Gestão de Empreendimentos Solidários.

Abstract: As field of work, the Solidarity Economy is an differentiated alternative to build opportunities for income generation and socio-productive inclusion it is projected on Solidary Economic Enterprises the capable of generating development with greater appreciation of human beings and the environment This article provides a discussion of Solidarity Economy in the west catarinese, with the goal of understanding the prospects of their actions, considering the characteristics of management, supporting institutions and operational policy challenges. It uses the mixed method research, once it allows cut and merge quantitative and qualitative data and providing greater legitimacy and improving the understanding of the categories and variables that are expressed around the object studied. We used the search field in the range of Amosc and Ameosc micro-regions. In Ameosc were surveyed Solidarity Economic Enterprises (SEE) and supporting institutions of their actions and Amosc, only those institutions. For field research with the selected subject (representatives of enterprises and leaders) made use of forms and interviews. As regards the legal formalization, stands out the association's form, the most common among Solidary Economic Enterprises of tow microregions. Among the productive activities of enterprises, stands out the production of food and handicrafts. The self-managed mode adopted in the surveyed enterprises has provided, in particular, integration between partners and additional income generation. Notwithstanding, there are difficulties to be overcome: low education workers; diversification and product differentiation and, little involvement of members in the management of the enterprise. Furthermore dynamic management of SEE also has political and operational difficulties to be overcome: limited commercial coverage and participation in networks; appropriate legal formalization for expand trade and investment opportunities. Once fortified, are able to promote dialogue for the formulation and implementation of policies from government agencies. The supporting Institutions of solidarity enterprises are varied within the sphere of government and non-governmental, providing access to the infrastructure and technical-management guidance and training in professional and policy fields. However, one of the great political and operational challenges in the field of Solidarity Economy permeates by the lack of legal formalization, which hamper many enterprises to sell at the state level, once overcome, would resolve the products difficulties of commercialization. (o texto não é o mesmo na parte final, pelo menos) 
Keywords: Solidarity economy. Socio-productive inclusion. Management of Solidarity Enterprises.

\section{INTRODUÇÃO}

A Economia Solidária, na opinião de Singer (2002), tem sido uma resposta importante dos trabalhadores e dos movimentos sociais em relação às transformações ocorridas no mundo do trabalho e à nova etapa do capitalismo. Etapa essa caracterizada pelo desemprego estrutural e pela desvalorização do trabalho produtivo em relação à acumulação financeira. Conforme Simionatto (2006), o processo de globalização - que prometia conquistas de bem-estar social, econômico e político para todos os povos e nações - transformou-se em "financeirização" da economia, obstaculizando processos ampliados de distribuição de bens e riquezas socialmente produzidos.

O processo de globalização na região oeste catarinense impactou consideravelmente na reestruturação da matriz produtiva, que, conforme Poli (2006), intensificou o êxodo rural e a concentração urbana da população. Anterior a essa reestruturação, a economia do oeste catarinense se caracterizava basicamente pela agricultura familiar introduzida durante o processo de colonização - pautado por valores e formas de organização da produção e da vida comunitária e demarcado pela chegada dos imigrantes europeus, que buscavam na agricultura familiar e camponesa um elemento estruturador e dinamizador para o desenvolvimento socioeconômico da região.

Com o passar dos anos, o processo de globalização e reestruturação produtiva - com o intuito de modernização do campo acabou por trazer à referida região um padrão tecnológico danoso ao ambiente e dependente da indústria, impondo máquinas, sementes selecionadas, adubação química e o uso de agrotóxicos (POLI, 2006). Com isso, a agricultura familiar e camponesa do oeste catarinense se organiza, em meio aos movimentos sociais, para viabilizar uma diversidade de iniciativas de produção que tinham por base os princípios de cooperação, autogestão, sustentabilidade e solidariedade, os quais podem ser abarcados pelo conceito da Economia Solidária.

A Economia Solidária como modo alternativo de trabalho e renda não assalariado, reúne pessoas que trabalham para garantir sua 
subsistência e melhorar sua condição de vida, uma vez que "[...] se unem em redes e/ou cooperativas de produção e comercialização, nas quais eles são proprietários ou sócios dos negócios, em vez de buscar emprego assalariado numa empresa capitalista" (PITAGUARI, 2010, p.11).

O movimento da Economia Solidária, ao evocar "[...] aspectos como a cooperação, solidariedade, propriedade coletiva dos meios de produção, o fim da mais-valia e a autogestão democrática", pode ser entendido "[...] como uma alternativa para superar as relações econômicas e produtivas capitalistas, sendo uma forma contrahegemônica de luta contra a dominação direta do capital sobre as forças produtivas sociais" (VALENTIM, JR.; SOBOTTKA, 2008, p.1).

Este estudo, em torno das perspectivas das ações de Economia Solidária na abrangência da região oeste catarinense, é parte integrante da dissertação de mestrado apresentada junto ao Programa de PósGraduação Strico Sensu, Políticas Sociais e Dinâmicas Regionais da Universidade Comunitária da Região de Chapecó-Unochapeco. Delimitado nas microrregiões da Amosc e Ameosc ${ }^{1}$, orienta-se por uma questão central: como se configuram as perspectivas das ações no campo da Economia Solidária, em suas estratégias e oportunidades de inclusão sócio-produtivas no oeste catarinense? Nessa direção, os objetivos de reconhecer instrumentos e mecanismos que dinamizam a gestão dos EES; de identificar limites e potencialidades de participação de segmentos e organizações da região, na formulação de diretrizes e políticas em defesa das ações de Economia Solidária; e, de demarcar desafios político-operacionais existentes para impulsionar as ações no campo da Economia Solidária, estruturam a descrição contida neste artigo.

\section{METODOLOGIA}

1 Conforme Dias e Marques (2003), um estudo efetuado pelo Instituto Brasileiro de Administração Municipal (Ibam) em 1978 - apontava as Associações de Municípios (AM) em Santa Catarina como sendo uma das mais antigas existentes no Brasil. Essas associações são entidades jurídicas de direito privado, sem fins lucrativos, com duração indeterminada e estatuto próprio. Os estatutos das associações manifestam a necessidade sentida pelas administrações municipais de integrar os municípios, como estratégia para fortalecer o atendimento das necessidades de infraestrutura para 0 desenvolvimento regional. 
Este estudo é apoiado no método misto de pesquisa por, primeiramente, ter feito um recorte quantitativo e, em seguida, ter se utilizado de estratégias qualitativas, com intuito de compreender categorias e variáveis que se expressaram no seu percurso.

Os dados quantitativos coletados foram extraídos de fontes secundárias, junto ao Ministério do Trabalho e Emprego-MTE, por meio da Secretaria Nacional de Economia Solidária (Senaes), disponíveis no Atlas da Economia Solidária no Brasil (2005-2007) e no Sistema Nacional de Informações em Economia Solidária-Sies (2010-2012). Já os dados qualitativos, foram obtidos pelos diálogos estabelecidos junto aos representantes dos EES e de organizações apoiadoras.

Como estratégia de estudo, valeu-se do estudo de caso, uma vez que o conhecimento que se possui dos fenômenos individuais, organizacionais, sociais, políticos e de grupo podem ser produzidos a partir da contribuição de estudos de caso (YIN, 2005). A adoção dessa estratégia resultou da necessidade de entender as perspectivas da Economia Solidária e seus empreendimentos na região oeste catarinense, com suas características e mudanças ocorridas.

As associações de municípios no estado catarinense têm sido uma das formas para enfrentar questões ligadas à gestão municipal e ao desenvolvimento econômico e social, por meio da construção de uma identidade político-territorial. A Figura 1 apresenta a relação das 21 associações de municípios existentes no Estado de Santa Catarina².

\footnotetext{
2 As associações que abrangem a "grande" região oeste catarinense são: Associação dos Municípios do Extremo Oeste Catarinense (Ameosc); Associação dos Municípios do Entre Rios (Amerios); Associação dos Municípios do Nordeste Catarinense (Amnoroeste); Associação dos Municípios do Oeste de Santa Catarina (Amosc); Associação dos Municípios do Alto Irani (Amai); Associação dos Municípios do Alto Uruguai Catarinense (Amauc); Associação dos Municípios do Meio Oeste Catarinense (Ammoc) e Associação dos Municípios do Alto Vale do Rio do Peixe (Amarp).
} 


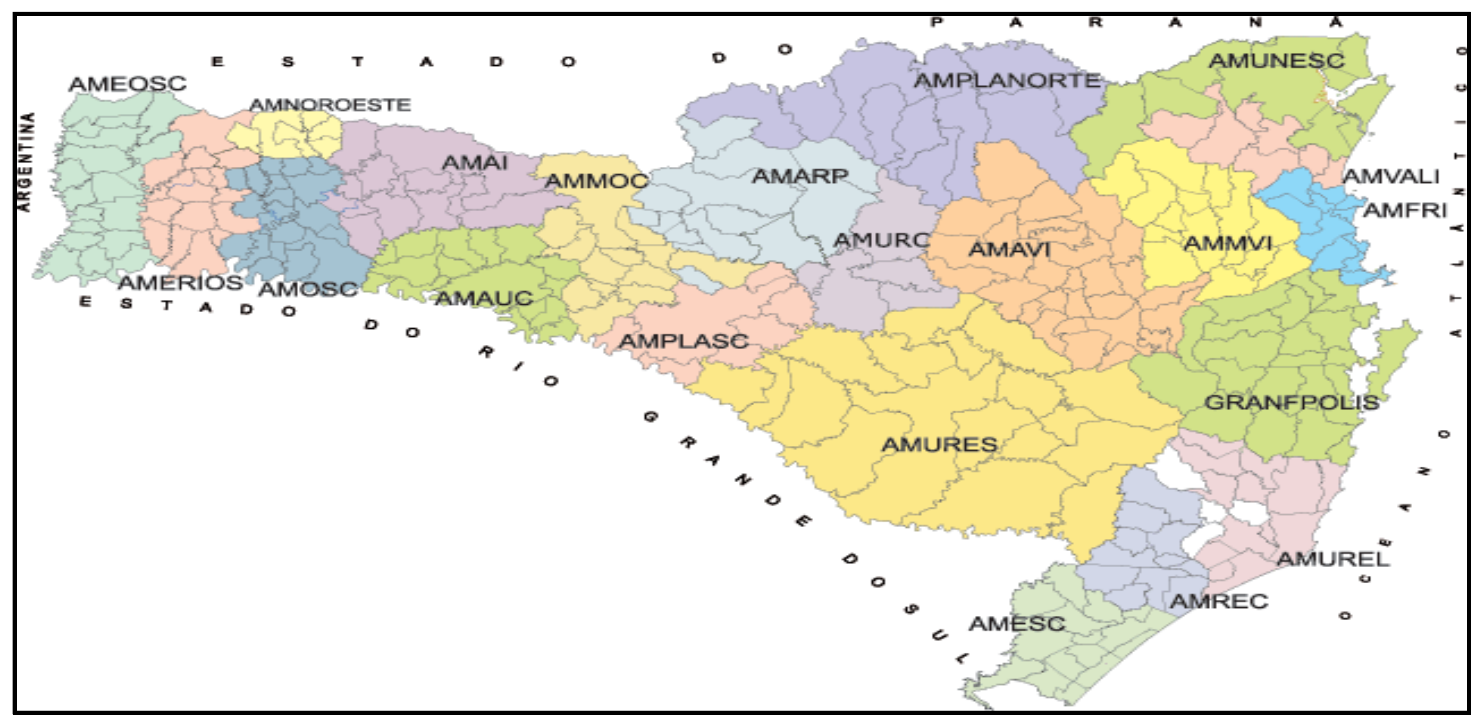

Figura 1. Associações de municípios existentes no estado de Santa Catarina. Fonte: Federação Catarinense de Municípios (Fecam), 2012.

A pesquisa de campo foi iniciada em Junho de 2013 na microrregião da Ameosc, deslocando-se aos municípios e respectivos empreendimentos, onde foi possível obter contato e agendamento com seus responsáveis, considerando a disponibilidade entre "equipe pesquisadora e pesquisados". Com isso, os municípios de Guaraciaba, Guarujá do Sul, Iporã do Oeste, Itapiranga, Palma Sola e São Miguel do Oeste foram os incluídos.

Após as primeiras aplicações dos formulários, junto aos responsáveis dos empreendimentos nessa microrregião ${ }^{3}$, encaminhouse para a realização de entrevistas com representantes de duas organizações apoiadoras dos empreendimentos solidários da Ameosc: Consórcio Intermunicipal de Saúde do Extremo Oeste e de Segurança Alimentar, Atenção à Sanidade Agropecuária e Desenvolvimento LocalConsad Extremo ${ }^{4}$ e o Instituto Acordar 5 . Nessas entrevistas, dialogou-se sobre questões acerca: da estrutura organizacional; do quadro de

3 Dos 15 empreendimentos econômicos solidários selecionados para pesquisa de campo, com 13 deles os formulários foram aplicados in loco. Os outros dois enviaram o formulário preenchido, via correio.

${ }^{4}$ Entre as estratégias de atuação do Consad Extremo para implementação dos projetos, está a construção de uma identidade econômica solidária no território, visando "a economia solidária para ajudar a eliminar a pobreza e promover a segurança alimentar" (FIORENTIN, 2012, p.158). Assim, considera a Economia Solidária como um processo de desenvolvimento de sua região de atuação.

5 O Instituto Acordar, conjuntamente com o Consad Extremo, são apoiadores do Fórum Extremo Oeste de Economia Solidária (Feoes). 
colaboradores; da forma de atuação; do tipo de apoio realizado aos EES e; dos desafios e perspectivas da Economia Solidária na região.

$\mathrm{Na}$ sequência da pesquisa de campo, em Janeiro e Fevereiro de 2014, ocorreu a aproximação junto aos representantes de seis organizações apoiadoras da Economia Solidária na microrregião da Amosc: Cáritas6; Fórum Regional Oeste de Economia Solidária ${ }^{7}$ - Fres; Instituto de Estudos e Assessoria ao Desenvolvimento ${ }^{8}$ (Ceades); Cooperativa de Construção Civil e Habitação Casa Nova ${ }^{9}$ - Cooper Casa Nova; Incubadora Tecnológica de Cooperativa Popular10 - ITCP da Unochapecó; e, Instituto de Desenvolvimento Regional Saga ${ }^{11 .}$ Essa aproximação se deu a fim de obter informações sobre questões relacionadas: à visão sobre atuação e expressão da economia solidária; ao seu potencial para o desenvolvimento da região; aos instrumentos e mecanismos apoiadores das ações de Economia Solidária; e, aos desafios enfrentados.

A escolha da região oeste de Santa Catarina se deve ao fato do número de empreendimentos solidários atingir um índice significativo se comparado às demais regiões no âmbito estadual. Apesar de apenas

${ }^{6}$ A Cáritas é uma organização não governamental, sem fins lucrativos e possui uma longa trajetória de projetos sociais, incluindo projetos para fortalecer EESs.

${ }^{7}$ O Fórum Regional Oeste de Economia Solidária (Fres), foi constituído em 2005 e contou com esforços de importantes instituições engajadas no desenvolvimento da Economia Solidária na região, bem como de representantes da sociedade civil.

8 O Ceades é uma organização autônoma que atua no campo popular, buscando potencializar processos de desenvolvimento local e territorial.

9 A Cooper Casa Nova foi fundada em abril de 2004 no município de Chapecó, por um grupo de trabalhadores (as) que se reuniram buscando melhorar as condições de trabalho e renda dos participantes, por meio da auto-gestão em um empreendimento cooperado

${ }^{10} \mathrm{~A}$ ITCP da Unochapecó iniciou suas atividades em 2001 a partir das experiências acumuladas pela rede da Unitrabalho, vinculada às Pró-Reitorias de Extensão das Universidades, somadas às experiências mais antigas de outras ITCP's (em capitais como Rio de Janeiro, São Paulo e Recife)

11 O Instituto de Desenvolvimento Regional Saga foi criado em 1998, sendo instrumento regional para apoiar o Fórum de Desenvolvimento Regional Integrado (FDRI), sediado e coordenado pela Amosc. Caracterizado como agência de desenvolvimento, é uma Organização Social de Interesse Público (OSCIP), portanto, sem fins lucrativos. Seu objetivo é integrar as ações e as políticas públicas de diversos municípios, buscando acelerar o desenvolvimento sócio-econômico regional do estado de Santa Catarina 
$19 \%$ da população catarinense estar fixada na região oeste, $47 \%$ dos empreendimentos econômicos solidários existentes no estado estão estabelecidos nessa região. Esse dado percentual (re)afirma sua vocação para as ações de Economia Solidária.

A delimitação da Ameosc e da Amosc, como microrregiões a serem pesquisadas, foi apoiada pelo levantamento de dados realizado com base no Atlas da Economia Solidária (2005-2007) que indicou, em termos quantitativos, a distribuição dos empreendimentos existentes por associação de municípios. Esse levantamento demonstrou que mais da metade dos EESs (61\%) da região oeste catarinense estão concentrados na Ameosc e Amosc. Ainda, foi apoiado pelo Catálogo dos Empreendimentos em Economia Solidária de Santa Catarina da Unochapecó (2007), além das informações obtidas junto aos técnicos da ITCP, vinculada à Unochapecó.

\section{ATUAÇÃO E CARACTERÍSTICAS DOS EMPREENDIMENTOS ECONÔMICOS SOLIDÁRIOS}

Com base nos dados do Sies (2010-2012), o número de pessoas que atuam no conjunto dos 152 EESs da Ameosc ${ }^{12}$ atingiu 16.281 pessoas em 2010, caracterizando-se como uma expressiva alternativa de inclusão sócio-produtiva para os trabalhadores dessa região. Ressalta-se que a Ameosc, atualmente, possui mais que o dobro de número de EES do que a Amosc: 152 e 76, respectivamente.

Referente à atuação dos empreendimentos dessa microrregião, conforme o Quadro 1, a fabricação de produtos alimentícios é a

\footnotetext{
12 Fundada em 1971 com a participação associativa de 19 municípios - Dionísio Cerqueira, Palma Sola, Guarujá do Sul, Princesa, São José do Cedro, Anchieta, Guaraciaba, Paraíso, Barra Bonita, São Miguel do Oeste, Bandeirante, Descanso, Belmonte, Santa Helena, Tunápolis, Iporã do Oeste, Mondaí, São João do Oeste e Itapiranga - a Associação dos Municípios do Extremo Oeste de Santa Catarina (Ameosc) é uma instituição gerenciada com recursos de seus municípios formadores, objetivando o desenvolvimento integrado da região, por meio da coordenação e estabelecimento conjunto de políticas públicas e da prestação de serviços técnicos especializados (AMEOSC, 2013).
} 
principal atividade produtiva (reflexo da sua vocação agroalimentar), sendo que $80 \%$ dos empreendimentos são rurais.

\begin{tabular}{|c|l|}
\hline Total de EES & Segmento Econômico \\
\hline 43 & Fabricação de Produtos Alimentícios \\
\hline 33 & Agricultura, Pecuária e Serviços Relacionados \\
\hline 29 & $\begin{array}{l}\text { Comércio por Atacado, Exceto Veículos Automotores e } \\
\text { Motocicletas }\end{array}$ \\
\hline 20 & Comércio Varejista \\
\hline 28 & Outros/Diversos \\
\hline
\end{tabular}

Quadro 1 - Total de EES por segmento econômico na região da Ameosc.

Fonte: SIES 2010-2012, (2013).

Os empreendimentos selecionados na abrangência da Ameosc são apresentados no Quadro 2, com as seguintes informações: ano de criação; principais atividades produtivas; avanços conquistados; e dificuldades a serem superadas.

\begin{tabular}{|c|c|c|c|c|c|}
\hline Municípios & Empreendimentos & $\begin{array}{l}\text { Ano de } \\
\text { Criação }\end{array}$ & $\begin{array}{l}\text { Atividade } \\
\text { produtiva } \\
\text { principal }\end{array}$ & Avanços conquistados & $\begin{array}{c}\text { Dificuldades a serem } \\
\text { superadas }\end{array}$ \\
\hline \multirow{2}{*}{$\begin{array}{l}\text { Iporã do } \\
\text { Oeste }\end{array}$} & $\begin{array}{l}\text { Cooperativa da } \\
\text { Agricultura Familiar } \\
\text { de Iporã do Oeste } \\
\text { (Coafio) }\end{array}$ & 2007 & $\begin{array}{l}\text { Produção de } \\
\text { alimentos }\end{array}$ & $\begin{array}{l}\text { Maior acesso ao } \\
\text { conhecimento técnico, } \\
\text { permanência no } \\
\text { mercado, balizar o } \\
\text { preço do mercado }\end{array}$ & $\begin{array}{l}\text { Escolaridade dos cooperados, } \\
\text { ampliação do número de } \\
\text { produtos, definição de uma } \\
\text { marca e parcerias com outros } \\
\text { empreendimentos. }\end{array}$ \\
\hline & Agroindústria Jundiá & 1999 & $\begin{array}{l}\text { Produção de } \\
\text { Doces }\end{array}$ & Não declarou & $\begin{array}{l}\text { falta de incentivo à produção } \\
\text { de cana, a falta de } \\
\text { conhecimento técnico do } \\
\text { agricultor, altos custos da } \\
\text { matéria-prima, diversificação } \\
\text { dos produtos }\end{array}$ \\
\hline \multirow{2}{*}{$\begin{array}{l}\text { Guarujá do } \\
\text { Sul }\end{array}$} & $\begin{array}{l}\text { Associação de } \\
\text { Artesãos de Guarujá } \\
\text { do Sul (ARTGS) }\end{array}$ & 1987 & Artesanato & $\begin{array}{l}\text { Despertar para as } \\
\text { vantagens de se } \\
\text { trabalhar } \\
\text { solidariamente e } \\
\text { formação de um } \\
\text { espírito solidário dos } \\
\text { associados }\end{array}$ & $\begin{array}{l}\text { Pouco envolvimento dos } \\
\text { associados na gestão do } \\
\text { empreendimento. }\end{array}$ \\
\hline & $\begin{array}{l}\text { Cooperativa de } \\
\text { Produtos da } \\
\text { Agricultura Familiar e } \\
\text { Economia Solidária } \\
\text { de Guarujá do Sul } \\
\text { (Cooperflor) }\end{array}$ & 2008 & $\begin{array}{l}\text { produção de } \\
\text { leite }\end{array}$ & $\begin{array}{l}\text { Valor agregado aos } \\
\text { produtos e capacidade } \\
\text { de elaboração de } \\
\text { projetos para captação } \\
\text { de recursos }\end{array}$ & $\begin{array}{l}\text { Produção de produtos } \\
\text { diferenciados, agregando valor } \\
\text { ao leite produzido pela } \\
\text { cooperativa }\end{array}$ \\
\hline
\end{tabular}




\begin{tabular}{|c|c|c|c|c|c|}
\hline & Velas Artesanais & 2006 & $\begin{array}{l}\text { produção de } \\
\text { velas }\end{array}$ & $\begin{array}{l}\text { O reconhecimento da } \\
\text { qualidade do trabalho } \\
\text { desenvolvido }\end{array}$ & $\begin{array}{l}\text { Falta de demanda no } \\
\text { município e o baixo poder } \\
\text { aquisitivo local. }\end{array}$ \\
\hline \multirow{2}{*}{ Guaraciaba } & $\begin{array}{l}\text { Associação } \\
\text { Manipuladores de } \\
\text { Alimentos de } \\
\text { Guaraciaba (Amag) }\end{array}$ & 2007 & $\begin{array}{l}\text { Produção de } \\
\text { alimentos }\end{array}$ & $\begin{array}{l}\text { Melhora na convivência } \\
\text { entre os associados }\end{array}$ & $\begin{array}{l}\text { Falta de apoio dos órgãos } \\
\text { públicos }\end{array}$ \\
\hline & $\begin{array}{l}\text { Usina de } \\
\text { Beneficiamento de } \\
\text { Leite Irmãos Diehl }\end{array}$ & 2005 & $\begin{array}{l}\text { Produção de } \\
\text { leite e } \\
\text { derivados }\end{array}$ & $\begin{array}{l}\text { Adesão ao Sistema } \\
\text { Único de Atenção à } \\
\text { Sanidade Agropecuária } \\
\text { (Suasa) }\end{array}$ & Aperfeiçoar a Comercialização \\
\hline \multirow{5}{*}{ Palma Sola } & $\begin{array}{l}\text { Associação dos } \\
\text { Artesãos e Artistas } \\
\text { Plásticos Belas Artes } \\
\text { de Palma Sola } \\
\text { (Artesanato Belas } \\
\text { Artes) }\end{array}$ & 2008 & Artesanato & $\begin{array}{l}\text { Geração de renda, } \\
\text { conquista do local de } \\
\text { venda e a visibilidade } \\
\text { no município }\end{array}$ & $\begin{array}{l}\text { Falta de integração entre os } \\
\text { associados e de interesse pela } \\
\text { gestão, }\end{array}$ \\
\hline & $\begin{array}{l}\text { Associação dos } \\
\text { Apicultores de Palma }\end{array}$ & 2000 & Mel & $\begin{array}{l}\text { Melhora nas vendas e } \\
\text { desenvolvimento da } \\
\text { marca }\end{array}$ & $\begin{array}{l}\text { Motivação dos associados, a } \\
\text { legislação burocrática, a falta } \\
\text { de inspeção sanitária e o } \\
\text { êxodo rural }\end{array}$ \\
\hline & Agromilps & 2008 & $\begin{array}{l}\text { Leite e } \\
\text { Derivados }\end{array}$ & $\begin{array}{l}\text { Confiança e integração } \\
\text { dos associados, além } \\
\text { da qualidade } \\
\text { transmitida do produto }\end{array}$ & $\begin{array}{l}\text { falta de vendas fora do } \\
\text { município, não possuem uma } \\
\text { sede própria, inexistência de } \\
\text { uma embalagem } \\
\text { personalizada, falta de um } \\
\text { carro para transporte } \\
\text { (refrigerado) e um local de } \\
\text { vendas. }\end{array}$ \\
\hline & $\begin{array}{l}\text { Associação } \\
\text { Vitinicultores de } \\
\text { Barra Grande }\end{array}$ & 2003 & Vinho & $\begin{array}{l}\text { Melhora no cultivo da } \\
\text { uva }\end{array}$ & $\begin{array}{l}\text { permanência dos } \\
\text { trabalhadores no campo, } \\
\text { estrutura logística e baixa } \\
\text { participação dos associados } \\
\text { na gestão. }\end{array}$ \\
\hline & $\begin{array}{l}\text { Associação dos } \\
\text { Feirantes de Palma } \\
\text { Sola }\end{array}$ & 2000 & $\begin{array}{l}\text { Produção e } \\
\text { comerciali- } \\
\text { zação de } \\
\text { alimentos }\end{array}$ & Não declarou & $\begin{array}{l}\text { Geração de renda adequada e } \\
\text { alcançar a conscientização e a } \\
\text { politização dos sócios. }\end{array}$ \\
\hline \multirow[b]{2}{*}{ Itapiranga } & $\begin{array}{l}\text { Associação Cultural } \\
\text { dos Artesãos e } \\
\text { Artistas Plásticos de } \\
\text { Itapiranga (Acaplai) }\end{array}$ & 2002 & Artesanato & $\begin{array}{l}\text { Instalação de seu } \\
\text { ponto de venda, cedido } \\
\text { pela prefeitura } \\
\text { municipal }\end{array}$ & $\begin{array}{l}\text { Baixo número de sócios, } \\
\text { vendas no ponto comercial e } \\
\text { diversificação dos produtos. }\end{array}$ \\
\hline & $\begin{array}{l}\text { Altenhofen Comercio } \\
\text { de } \\
\text { Hortifrutigranjeiros } \\
\text { Ltda, cujo nome } \\
\text { fantasia é LA } \\
\text { Produtos Coloniais }\end{array}$ & 2002 & $\begin{array}{l}\text { Cultivo e a } \\
\text { comerciali- } \\
\text { zação da } \\
\text { mandioca }\end{array}$ & $\begin{array}{l}\text { Aumento na produção } \\
\text { e na demanda }\end{array}$ & Armazenamento \\
\hline
\end{tabular}

Quadro 2. Municípios e características dos Empreendimentos Econômicos Solidários pesquisados na Ameosc.

Fonte: Elaboração com base na pesquisa de campo.

Observam-se avanços importantes que caracterizam os EESs no que se refere: ao acesso a conhecimentos técnicos (embora ainda 
necessários); à permanência no mercado; ao aperfeiçoamento do trabalho com formação de espírito solidário; ao valor agregado e melhoria da qualidade dos produtos; ao desenvolvimento da capacidade de elaboração de projetos para captação de recursos; à adesão ao Sistema Único de Atenção à Sanidade Agropecuária-Suasa; à geração complementar de renda; e à conquista de um espaço exclusivo para produção (geralmente cedido).

Conforme os dados do Sies (2010-2012), 44.736 pessoas atuavam em 76 EESs na Amosc ${ }^{13}$. Entretanto, apenas um empreendimento, a Cooperativa de Habitação dos Agricultores Familiares dos Três Estados do Sul-Cooperhaf com sede no Município de Chapecó, agrega 32.107 pessoas associadas em toda Mesorregião da Grande Fronteira Sul.

A principal atuação dos empreendimentos dessa microrregião é a Fabricação de Produtos Alimentícios, seguida do Comércio Varejista e das Atividades de Serviços Financeiros.

\begin{tabular}{|c|l|}
\hline Total de EES & Segmento Econômico \\
\hline 18 & Fabricação de Produtos Alimentícios \\
\hline 14 & Comércio Varejista \\
\hline 9 & Atividades de Serviços Financeiros \\
\hline 7 & Fabricação de Produtos Têxteis \\
\hline 6 & Fabricação de Produtos Diversos \\
\hline 5 & Agricultura, Pecuária e Serviços Relacionados \\
\hline 5 & $\begin{array}{l}\text { Comércio Por Atacado, Exceto Veículos Automotores e } \\
\text { Motocicletas }\end{array}$ \\
\hline 9 & Outros/Diversos \\
\hline
\end{tabular}

Quadro 3. Total de EESs por Segmento Econômico na região da Amosc.

Fonte: Base de Dados SIES 2010-2012 (2013).

13 A Associação dos Municípios do Oeste de Santa Catarina (Amosc) foi criada em 11 de fevereiro de 1968, com o intuito de defender os interesses dos municípios associados - terceira Associação de Município criada no Estado de Santa Catarina. Com sede em Chapecó, a Amosc conta, hoje, com 20 municípios da região oeste (Águas de Chapecó, Águas Frias, Caxambu do Sul, Chapecó, Cordilheira Alta, Coronel Freitas, Formosa do Sul, Guatambu, Irati, Jardinópolis, Nova Erechim, Nova Itaberaba, Planalto Alegre, Pinhalzinho, Quilombo, Santiago do Sul, São Carlos, Serra Alta, Sul Brasil e União do Oeste) AMOSC (2013). 
Ao analisar os segmentos econômicos de atuação dos EESs nas duas microrregiões, observa-se que a fabricação de produtos alimentícios é a principal atividade produtiva, sendo reflexo da vocação agroalimentar dos empreendimentos, principalmente na Ameosc. Já na Amosc, destacam-se os serviços financeiros, uma vez que, mesmo com sede no conjunto de municípios dessa microrregião, atuam na abrangência da região oeste.

\section{GESTÃO DOS EMPREENDIMENTOS ECONÔMICOS SOLIDÁRIOS E AS INSTITUIÇÕES APOIADORAS}

$\mathrm{Na}$ opinião dos associados dos EESs e dos representantes das instituições apoiadoras, a Economia Solidária como campo de ação tem enfrentado um conjunto de dificuldades. Consideram que a relação dos empreendimentos solidários está "muito frágil com o poder público", depositando nas ONGs uma alternativa de apoio ${ }^{14}$.

[...]. A alternativa de fortalecimento [...] tem sido as ONG's, não só a Cáritas, mas a gente tem conhecimento de outras que têm trabalhado com esses empreendimentos em âmbito nacional, mas com o poder publico é muito complicado, muito fragilizado ainda (S.K., Chapecó, 2014).

$\mathrm{Na}$ região da Ameosc, o Consad Extremo aparece como órgão apoiador, sendo citado várias vezes em diversos segmentos. Além disso, o referido Consórcio foi mencionado em diversas entrevistas entre os associados dos EESs da Ameosc. Conforme N. P. de Guarujá do Sul, "foi lá que eu entrei na Economia Solidária (referindo-se às reuniões e atividades realizadas pelo Consad Extremo). É [...] de chamar a gente para as reuniões, geralmente [...] arrumam as verbas para custear [...]." Nesse sentido, S.D. pontua que "o Consad tem sido uma espécie de 'barriga de aluguel' para apoiar esses empreendimentos entendidos econômicos solidários".

\footnotetext{
${ }^{14} \mathrm{O}$ poder público, de um modo geral, detém potencial para fomentar os empreendimentos solidários, tanto diretamente, através das compras públicas, quanto indiretamente, como apoiador de instituições da sociedade civil que atuam junto dos EESs.
} 
Não obstante, na região da Ameosc, os organismos governamentais também fornecem apoio aos empreendimentos solidários (Quadro 4), tendo sido citados em 126 oportunidades, conforme dados do Sies 2010-2012. Nessa direção, as prefeituras estão entre as principais apoiadoras, em especial, no momento em que os empreendimentos iniciam suas atividades. 


\begin{tabular}{|l|c|l|}
\hline \multicolumn{1}{|c|}{$\begin{array}{c}\text { Instituições apoiadoras por } \\
\text { segmento }\end{array}$} & $\begin{array}{c}\mathbf{N}^{\circ} \text { de } \\
\text { Apoios }\end{array}$ & Maiores apoiadoras por segmento \\
\hline Prefeitura/Secretarias & 63 & Secretaria da Agricultura \\
\hline Governo Estadual/Secretarias & 36 & Epagri \\
\hline Outras & 32 & Consad Extremo \\
\hline Governo Federal/Órgãos & 27 & MDS \\
\hline Sistema "S" (Sebrae, Sescoop, etc.) & 26 & Sebrae, SENAR, SENAl \\
\hline ONGs, OSCIPs & 21 & Consad, Ceades, Instituto Acordar \\
\hline $\begin{array}{l}\text { Movimento Sindical } \\
\text { (Central,sindicato, Federação) }\end{array}$ & 19 & Sintraf \\
\hline Entidade de representação & 14 & MMC - Movimento das Mulheres \\
Camponesas e Apaco
\end{tabular}

Quadro 4. Instituições apoiadoras aos EES da Ameosc.

Fonte: SIES 2010-2012 (2013).

$\mathrm{Na}$ região da Amosc, além dos organismos governamentais, destaca-se a atuação da ITCP da Unochapecó, revelando-se como expressiva apoiadora dos empreendimentos solidários nessa região (Quadro 5).

\begin{tabular}{|l|c|l|}
\hline Instituições apoiadoras por segmento & $\begin{array}{c}\mathbf{N}^{\mathbf{0}} \text { de } \\
\text { Apoios }\end{array}$ & Maiores apoiadoras por segmento \\
\hline $\begin{array}{l}\text { Universidades } \\
\text { Unitrabalho) }\end{array}$ & 23 & ITCP Unochapecó \\
\hline Prefeitura/Secretaria & 20 & $\begin{array}{l}\text { Secretaria da Agricultura, } \\
\text { Secretaria de Assistência Social }\end{array}$ \\
\hline Sistema "S" (Sebrae, Sescoop, etc.) & 18 & Sebrae, Senar \\
\hline Governo Estadual/Secretaria & 15 & Epagri \\
\hline Governo Federal/Secretaria & 12 & Ministério do Trabalho e Emprego \\
\hline Entidade de representação & 9 & Cresol \\
\hline
\end{tabular}




\begin{tabular}{|l|l|l}
\hline Outras & 19 & Apaco
\end{tabular}

Quadro 5. Fornecedores de Apoio aos EES da Amosc.

Fonte: SIES 2010-2012 (2013).

Os tipos de apoio mais recebidos pelos empreendimentos, na região da Amosc, conforme dados do Sies 2010-2012 (Quadro 6), referem-se: à qualificação profissional, técnica e gerencial (em 39 EES); à assistência técnica e/ou gerencial (em 36 EES); e, à formação sóciopolítica em autogestão, cooperativismo, economia solidária (em $33 \mathrm{EES}$ ). 


\begin{tabular}{|l|c|}
\hline Tipos de apoio recebido pelos empreendimentos & $\begin{array}{c}\text { No de } \\
\text { empreendimentos } \\
\text { apoiados }\end{array}$ \\
\hline Qualificação profissional, técnica e gerencial & 39 \\
\hline Assistência técnica e/ou gerencial & 36 \\
\hline $\begin{array}{l}\text { Formação sócio-política (autogestão, cooperativismo, economia } \\
\text { solidária) }\end{array}$ & 33 \\
\hline Assessoria na constituição, formalização ou registro & 16 \\
\hline Diagnóstico, planejamento e análise de viabilidade econômica & 15 \\
\hline Elaboração de Projetos & 13 \\
\hline $\begin{array}{l}\text { Assessoria em marketing e na comercialização de produtos e } \\
\text { serviços }\end{array}$ & 12 \\
\hline Incubação & 9 \\
\hline Assistência jurídica & 8 \\
\hline
\end{tabular}

Quadro 6. Número de empreendimentos apoiados, por tipo de apoio, na Amosc.

Fonte: SIES 2010-2012 (2013).

$\mathrm{Na}$ Ameosc, entre os empreendimentos registrados no Sies $2010-$ 2012, destacam-se apoios referentes à formação sócio-política autogestão, cooperativismo, economia solidária - (em 76 EES), além da qualificação profissional, técnica, gerencial (em $72 \mathrm{EES}$ ) e da assistência técnica e/ou gerencial (em 63 EES).

\begin{tabular}{|l|c|}
\hline Tipo de apoio recebido pelo empreendimento & $\begin{array}{c}\mathbf{N}^{\circ} \text { de } \\
\text { empreendimento } \\
\text { s apoiados }\end{array}$ \\
\hline $\begin{array}{l}\text { Formação sócio-política (autogestão, cooperativismo, economia } \\
\text { solidária) }\end{array}$ & 76 \\
\hline Qualificação profissional, técnica, gerencial & 72 \\
\hline Assistência técnica e/ou gerencial & 63 \\
\hline Assessoria na constituição, formalização ou registro & 36 \\
\hline Elaboração de projetos & 31 \\
\hline Assistência jurídica & 17 \\
\hline Diagnóstico, planejamento e análise de viabilidade econômica & 8 \\
\hline $\begin{array}{l}\text { Assessoria em marketing e na comercialização de produtos e } \\
\text { serviços }\end{array}$ & 7 \\
\hline Incubação & 1 \\
\hline
\end{tabular}

Quadro 7. Número de empreendimentos apoiados, por tipo de apoio, na Ameosc.

Fonte: SIES 2010-2012 (2013). 
Apesar do trabalho que o Consad Extremo desenvolve, especialmente junto aos empreendimentos da Ameosc, sobre a certificação sanitária como oportunidade de ampliar fronteiras comerciais para a maioria dos EESs (tanto na Ameosc quanto na Amosc), a comercialização dos produtos tem se limitado ao mercado comunitário e municipal. O Quadro 8 mostra essa restrita abrangência. 


\begin{tabular}{|l|c|c|}
\hline \multicolumn{1}{|c|}{ Abrangência Comercial } & $\begin{array}{c}\mathbf{N}^{\circ} \text { de EES na } \\
\text { Amosc }\end{array}$ & $\mathbf{N}^{\circ}$ de EES na Ameosc \\
\hline Mercado municipal & 34 & 64 \\
\hline Mercado comunitário & 33 & 36 \\
\hline Mercado microrregional & 18 & 38 \\
\hline Mercado estadual & 6 & 15 \\
\hline Mercado nacional & 0 & 6 \\
\hline Mercado externo & 0 & 2 \\
\hline
\end{tabular}

Quadro 8. Abrangência Comercial dos EES por Associação de Municípios.

Fonte: Atlas da Economia Solidária no Brasil 2005-2007.

Mesmo com a comercialização dos produtos sendo feita sistematicamente em área geográfica próxima aos empreendimentos, a certificação sanitária é um instrumento importante para dar vazão aos estoques contidos. É o que reforça V. T. ao considerar a produção de seu empreendimento suficiente tanto para abastecer o comércio local quanto outros.

Nós temos excessos de produção [...]. Tem um produtor com uma tonelada de mel estocada [...]. Estávamos aguardando a inspeção para comercializar fora de Palma Sola [...]. O principal comprador aqui é o PAA (se referindo ao Programa de Aquisição da Agricultura Familiar). (V.T., Palma Sola, 2014).

O Consad Extremo e a ITCP da Unochapecó estão posicionados como instituições que mais apoiam os EESs na abrangência da Ameosc e Amosc. Esse fato mostra a importância e a necessidade de aplicar maiores investimentos financeiros e técnicos, com o intuito de ampliar a capacidade de incubação e produção de tecnologias econômicas e sociais. Sem dúvida, trata-se de um mecanismo que opera a favor dos empreendimentos solidários no que se refere à qualificação profissional, técnica, gerencial e de formação sócio-política de seus associados.

As vendas diretas da produção aos órgãos governamentais está mais presente nos empreendimentos da Ameosc, pois conforme dados do Sies 2010-2012, dos 152 EESs existentes nessa Associação, 39 ou $25,65 \%$ realizam venda diretas aos órgãos governamentais, configurando sua segunda principal forma de comercialização (Tabela 1). Já na Amosc, apenas 11 EES ou 14,47\% do total de 76 EESs existentes 
utilizam essa forma governamental de comercialização. A maioria dos EESs (41 na Amosc e 65 na Ameosc) efetua a venda de seus produtos diretamente aos consumidores. Chama-se a atenção para a limitada relação de comercialização existente entre os próprios empreendimentos solidários, em especial na Amosc, o que sinaliza uma necessidade de aperfeiçoamento das redes de comércio solidário. 
Tabela 1. Formas de comercialização dos EESs por Associação de Município

\begin{tabular}{l|c|c}
\hline Formas de Comercialização dos EESs & AMOSC & AMEOSC \\
\hline Venda direta ao consumidor & 41 & 65 \\
\hline Venda a revendedores/atacadistas & 14 & 34 \\
\hline Venda a órgão governamental & 11 & 39 \\
\hline Troca com outros empreendimentos solidários & 3 & 2 \\
\hline Venda a outros empreendimentos solidários & 2 & 12 \\
\hline Outras formas de Comercialização & 6 & 5 \\
\hline
\end{tabular}

Fonte: Base de dados SIES 2010-2012 (2013).

Conforme dados do Sies 2010-2012, na Amosc, independente da comercialização, 28 empreendimentos informaram que participam de alguma forma de rede enquanto 48 não participam. Já na Ameosc, 29 participam e 123 ainda se colocam à margem dessa participação. 0 próprio isolamento da rede de Economia Solidária em relação a outras redes de comercialização afins se constitui como uma das dificuldades a ser enfrentada e superada pelo fato de gerar fragmentação e divergências entre os associados dos EESs.

Nesse sentido, é fundamental que haja um aperfeiçoamento na articulação com outros movimentos e lutas de trabalhadores, sem perder a centralidade da luta pelo trabalho associado e autogestionário. É importante "estreitar" laços com os "vínculos fracos" (GRANOVETTER,1973) e, sobretudo, "apostar na interlocução com os atores da rede que estão relativamente menos envolvidos nos debates e ações que os atores mais centrais, mas que funcionam como um ponto para o 'exterior', ou seja, as demais redes e organizações" (CUNHA, 2012, p.70).

\section{GESTÃO DA POLÍTICA DE ECONOMIA SOLIDÁRIA E MECANISMOS DINAMIZADORES}

Desde 2003, a Economia Solidária - como uma forma de produção, consumo e distribuição de riqueza e com sua finalidade multidimensional (social, econômica, política, ecológica e cultural) - tem galgado patamares na agenda pública do governo brasileiro, com expressão no cenário político e institucional em diferentes níveis. 
Contudo, o apoio do Estado à Economia Solidária e, em decorrência, aos empreendimentos com esse caráter se dispersa e ao mesmo tempo se complexifica, uma vez que diretrizes e ações em sua defesa estão sendo coordenadas por vários Ministérios. Além do MTE, onde a Senaes está situada, Cunha (2012) aponta que existe uma forte atuação nesse campo da Economia envolvendo os Ministérios de Desenvolvimento Social e combate à Fome - MDS, Desenvolvimento Agrário - MDA, Educação-MEC e Ciência e Tecnologia - MCT.

As políticas de Economia Solidária dependem, principalmente, da relação entre Estado e entidades da Sociedade Civil, no que se refere à execução de projetos de pequeno e médio portes, diferentemente do que ocorre com outras políticas da área social que contam com a atuação direta tanto do governo federal quanto de estados e municípios. No caso da Senaes, trata-se de uma estratégia de atuação importante devido aos seus limites de recursos e de estrutura ainda serem insuficientes para atuação consistente em âmbito nacional (CUNHA, 2012).

A Economia Solidária possibilita abertura a outros valores, além do econômico, como a solidariedade, a cooperação e a busca de soluções para os problemas locais que compõem a pauta de discussão dos mais variados empreendimentos. Nesse sentido, França Filho (2007, p.14) argumenta que "o campo da economia popular e solidária no Brasil se impõe também, cada vez mais, como um movimento de atores em busca de reconhecimento institucional", sendo as redes e fóruns expressões materializadas desse movimento de auto-organização política. A caracterização do que seja uma rede ou um fórum se torna um desafio, pois são dois modos de expressão de difícil distinção. Logo, França Filho (2007) busca fazer tal diferenciação ${ }^{15}$ apoiado tanto no

\footnotetext{
15"As redes são formas de auto-organização mais evidente e mais antiga. Elas consistem num associacionismo mais amplo, compreendendo certo número de experiências concretas de organizações de fomento e apoio que compartilham valores e regras comuns. As redes se estendem em diferentes escalas entre o local, o regional, o nacional e o internacional. As redes guardam um traço político forte ao constituírem-se exclusivamente a partir das experiências oriundas da sociedade, com independência em relação aos poderes públicos. [...] Os fóruns, por sua vez, também são espaços de reunião de atores, mas numa dimensão mais ampla, pois supõem, também, a participação de representantes de instituições públicas. Ao mesmo tempo em que reivindicam sua autonomia enquanto espaço de atores da
} 
debate político sobre o lugar de cada modo de auto-organização quanto sobre as relações que mantém entre si e com os poderes públicos.

Os fóruns se apresentam como interlocutores de destaque no campo da Economia Solidária, especialmente na articulação junto à Senaes do MTE, pois, além da organização de atores com origens bastante diversificadas, sua tarefa principal é subsidiar, por meio de proposições, a definição de políticas públicas para esse setor da economia.

Na região da Ameosc, o Consad Extremo e o Instituto Acordar são parceiros nessa tarefa de articular os atores da Economia Solidária no Fórum Extremo Oeste de Economia Solidária-Feoes. Entretanto, as dificuldades ainda são muitas, desde a falta de participação dos atores até o acesso aos recursos para viabilizar as atividades dos fóruns.

Desde o início, Instituto Acordar e Consad Extemo foram criados juntos, nós fazíamos muitos trabalhos em parceria. Dentro do Consad Extremo tinha uma linha de ação que era Economia Solidária. Na verdade, o Consad Extremo é que começou a discussão de trazer um fórum de Economia Solidária para o extremo oeste e nós, Instituto Acordar, fomos apoiando e constituímos o Fórum Extremo Oeste de Economia Solidária. Desde então, Acordar e Consad Extremo são as entidades de apoio ao fórum, ou seja, somos nós que mobilizamos o povo. (E. A, São Miguel do Oeste, 2013).

Na região da Amosc, o Fres enfrenta dificuldades para ampliar a participação dos associados nos debates e mobilizações, apesar do grande número de empreendimentos existentes.

O fórum se reúne uma vez por mês, sendo um espaço de reunião, de repasse de informação das demandas. Contudo, nas últimas reuniões o fórum se resumiu na participação de empreendimentos de três ou quatro municípios mais próximos [...]. Assim, o fórum é regional, mas no entanto, só consegue uma participação local. Além disso, tem sido um espaço de participação na maioria de empreendimento urbano, contrapondo-se ao que se conhece de que tem muito empreendimento rural [...]. (V.D, Chapecó, 2014)

sociedade civil, os fóruns se abrem para uma relação de interdependência em relação aos poderes públicos". (FRANÇA FILHO, 2007, p.170). 
A falta de tempo e disponibilidade dos associados para participarem das reuniões do FRES foram os motivos apresentados.

\begin{abstract}
Nosso articulador seria o Fórum Regional de Economia Solidária. No entanto temos um problema, nós precisamos produzir e às vezes o resultado do trabalho realizado nas reuniões é lento. Então, quando tem feiras ou quando tem coisas para fazer nós conseguimos participar e colaborar, mas nas reuniões normais eu tenho dificuldade [...], pois para se tirar um trabalhador que está na construção de um prédio para participar de uma reunião é extremamente complicado [...]. (J. A.,Chapecó. 2014).
\end{abstract}

Para a entrevistada M.A. (Chapecó, 2014) a falta de participação nos fóruns acontece porque "não é fomentada a participação [...], falta mobilização, mas, acima de tudo, falta conhecimento. Não sabem o que é Economia Solidária, as discussões são muito fechadas, tem que abrir mais isso. Ficamos discutindo entre nós mesmos [...]".

Os resultados da atuação dos fóruns em âmbito nacional podem ser destacados pelo aparecimento e a multiplicação das políticas públicas dedicadas à Economia Solidária que, Conforme França Filho (2007), ocorre significativamente em nível das prefeituras municipais.

Entretanto, o crescimento progressivo das políticas de Economia Solidária no Brasil não aconteceu sem problemas, pois é um tema que "[...] muitas vezes é captado, por certas estruturas de governo, como mais um modismo, apoiando-se, assim, em bases muito frágeis de tratamento da questão da geração de trabalho e renda" (FRANÇA FILHO, 2007, p.171).

As dificuldades na elaboração e implementação das políticas possibilitou o surgimento da rede brasileira de gestores de políticas públicas de economia solidária, um novo ator nesse campo, que vem desempenhando um importante papel, em parceria com a Senaes e outros atores, como a Fundação Josué de Castro, "[...] no nivelamento necessário para a compreensão do tema, que passa por um intenso programa de formação dos gestores públicos em seus diferentes níveis" (FRANÇA FILHO, 2007, p.171).

Além da falta de formação e capacitação para se implementar corretamente políticas de economia solidária, a falta de interesse dos órgãos públicos foi citada por um dos entrevistados. 
O poder público estadual e municipal eles não estão conseguindo nos enxergar, eles nos vêem como uma força contra os interesses liberais deles, [...] então eles não apóiam. O estado criou uma secretaria e um conselho, depois de muita pressão do próprio Fórum Catarinense de Economia Solidária, mas são muito lentos, despolitizados, levam as coisas muito do jeito que querem, falta muito conhecimento, não estão preparados para fazer o diálogo com o governo federal e com a Senaes [...], porque, talvez o interesse não seja desenvolver o cooperativismo. (J. A.,Chapecó, 2014).

Nas microrregiões do oeste catarinense (Ameosc e Amosc), conforme relatos dos entrevistados representantes das instituições apoiadoras, nem todas as prefeituras estão capacitadas para oferecer apoio aos empreendimentos solidários, apresentando ações desconexas e pontuais ao invés de uma política definida e estruturante de ações coordenadas. Apesar das prefeituras serem apontadas pelos dados do Sies 2010-2012 como uma das principais apoiadoras, como visto em item anterior, a falta de continuidade no apoio foi sinalizado na seguinte fala: "[...] quando começamos, não dá pra dizer que houve um apoio da prefeitura, pois somente reuniram os artesãos, mas nos abandonaram no caminho [...]" (M. B., Itapiranga, 2013).

O embate político parece um caminho necessário ao processo de desenvolvimento da Economia Solidária, assim como a conscientização de que essa outra economia existe.

\begin{abstract}
A economia não capitalista não vai estar nas grandes cadeias produtivas ou nos setores de interesse do capital. Então, ela é uma economia marginal, vem se fortalecendo, vem criando visibilidade [...]. Contudo, ela não é visível, porque não se quer que ela seja visível e que ela traga à tona os conflitos, contradições ou aguças da economia capitalista. (C. A., Chapecó, 2013).
\end{abstract}

Não obstante, a partir da criação da Senaes, vinculada ao Ministério do Trabalho, os canais de comunicação e participação dos movimentos de lutas pela Economia Solidária como o Estado foram ampliados, sendo os fóruns interlocutores mas sem, efetivamente, ampliar a participação dos atores dos empreendimentos solidários. 
Entretanto, essa articulação estabelecida com a via federal passa a exigir ações articuladas conjuntamente com os governos estadual e municipal.

\section{DESAFIOS POLÍTICO-OPERACIONAIS DAS AÇÕES NO CAMPO DA ECONOMIA SOLIDÁRIA}

Entre as barreiras a serem superadas pelos empreendimentos solidários no tocante a ampliar a abrangência comercial, cita-se a falta de formalização jurídica, pois dos empreendimentos existentes tanto na Amosc quanto na Amesoc, $44,10 \%$ são associações e $31,87 \%$ são caracterizados como grupos informais (Sies 2010-2012).

A falta de formalização jurídica específica para os EESs tem se tornado um obstáculo, pois a grande maioria dos empreendimentos são produtores de alimentos, exigindo o registro de Inspeção Sanitária. Conforme Santos (2012, p.311), "a inexistência de um marco legal para a área traz sérias dúvidas e dificuldades jurídicas para os empreendimentos solidários em vários aspectos como formalização jurídica, tributação e o acesso às aquisições públicas".

A dificuldade de comercialização dos empreendimentos solidários também é apontada como um dos desafios pelos apoiadores da Economia Solidária na Amosc.

A grande dificuldade que se tem hoje é com a comercialização dos produtos, tanto no meio rural quanto na cidade, principalmente na cidade de Chapecó que poderia ser um grande pólo, uma grande oportunidade para comercializar os produtos dos empreendimentos, isso não tem ocorrido. Nós percebemos uma questão, por vezes, política partidária que não tem dado oportunidade aos empreendimentos para comercializar. (S.K., Chapecó, 2014).

Para V. D. de Chapecó, uma possibilidade de ampliar a comercialização dos empreendimentos reside na criação de uma forma de Declaração de Aptidão (DAP) à Economia Solidária, assim como existe para a Agricultura Familiar16.

\footnotetext{
16 Por intermédio do Fórum Brasileiro de Economia Solidária - FBES (2013), na V Plenária Nacional de Economia Solidária, realizada de 09 a 13 de dezembro de 2012, em Luziânia (GO), esse tema foi apontado como uma prioridade para consolidação e fortalecimento do Sistema Nacional de Comércio Justo e Solidário (SCJS). Na ocasião,
} 
Conforme dados do Sies 2010-2012, na região da Amosc, 33 EESs têm como forma de organização a associação (gerando uma série de limitações) e 28 a cooperativa. Já o grupo informal soma 14 empreendimentos e a sociedade mercantil apenas um. No que se refere às barreiras enfrentadas pelos empreendimentos estão: a falta de uma forma de organização jurídica específica para os EESs; a dificuldade de comercialização e, em decorrência, a falta de capital de giro para se manter durante o período que abrange a compra dos fornecedores; a produção, venda e o recebimento de clientes; a estrutura para comercialização (local, espaço, equipamentos inexistente e/ou inadequada; e a indisponibilidade dos sócios para cuidar dessa atividade.

Na região da Ameosc, a principal forma de organização dos EESs é também a associação, revelada em 67 casos, sendo Guaraciaba e São Miguel do Oeste os municípios que mais possuem EESs com essa natureza, dez e sete associações, respectivamente. Outras formas de constituição dos empreendimentos na referida região se caracterizam por 59 grupos informais, 22 cooperativas e quatro sociedades mercantis (Sies 2010-2012, 2013).

Conforme a base de dados do Sies 2010-2012, a falta de uma forma de organização jurídica específica é um dos desafios políticooperacionais existentes para impulsionar as ações no campo da Economia Solidária. No âmbito da Ameosc a principal dificuldade de comercialização dos empreendimentos é não ter o registro legal (30 ocorrências), seguido da falta de capital de giro (25 ocorrências).

Os dados do Atlas da Economia Solidária no Brasil (2005-2007) apontam que a maior parte dos EESs, em âmbito nacional, não possui uma forma jurídica adequada para suas atividades. Segundo Sanchez (2012), mais de 50\% desses empreendimentos é formalizado como associação ${ }^{17}$. Reforça-se que, dentre as formas jurídicas apresentadas, a

essa declaração de aptidão ficou intitulada Declaração de Conformidade da Economia Solidária (DCESOL).

17 Considerando que o Código Civil define associação como organizações sem fins econômicos, esses empreendimentos têm diversas restrições na formalização de suas atividades como, por exemplo, a impossibilidade de emissão de notas fiscais, o que dificulta a comercialização para além dos mercados locais e municipais. Ainda, outros 36\% dos EES são informais, impossibilitando o Cadastro Nacional como Pessoa Jurídica (CNPJ) o que inviabiliza, por exemplo, o acesso a linhas de financiamentos e créditos. 
mais apropriada para um EESs se formalizar é a cooperativa, devido ao seu histórico e lutas contra a exploração do trabalho, seus princípios e características autogestionárias e participativas (SANCHEZ, 2012). Além disso, as cooperativas possuem direitos específicos reconhecidos na Constituição Federal que garante o apoio do Estado brasileiro.

Nessa direção, Sanchez (2012, p.345) afirma que "a estratégia deveria se focar em mudanças na lei do cooperativismo, de forma a reaproximar essa forma de organização de suas origens históricas e propiciar que EES se formalizem como tal". Assim, a luta política do movimento da Economia Solidária consistiria em reivindicar acesso aos direitos já assegurados para as cooperativas, como, por exemplo, os tratamentos tributários diferenciados, apoio do Estado e o acesso a fundos públicos como os recursos do Serviço Nacional de Aprendizagem do Cooperativismo.

Outro desafio a ser superado pelos EESs, conforme Sanchez (2012), é a dificuldade de acessar financiamentos. Esse fato é notório nas microrregiões estudadas, quando a falta de capital de giro se apresenta como maior dificuldade de comercialização dos empreendimentos, tanto na Amosc quanto na Ameosc.

Para laskio (2006), os EESs têm dificuldade de acumular recursos financeiros, considerando que não é um objetivo a ser perseguido e, além disso, que sua formação inicial geralmente é constituída com uma pequena quantidade de capital e equipamentos, muitas vezes, obsoletos.

As empresas de autogestão são formadas por pessoas que não possuem grande patrimônio pessoal e, normalmente, têm reduzido grau de instrução. Mesmo quando essas empresas têm à disposição equipamentos para trabalhar, estes costumam ser antigos e, muitas vezes, obsoletos. A falta de patrimônio

Finalmente, apenas 10\% (aproximadamente) estão formalizados como cooperativas que, "supostamente, seria a forma jurídica apropriada para a grande maioria dos EES, devido suas características organizacionais e políticas" (SANCHEZ, 2012, p.344). Com base no Sistema da Informação em Economia Solidária (Sies 2010-2012) mostra-se uma variação nos dados apresentados acima, qual seja: a maioria dos EES ainda está registrada como associação, sendo que atualmente representam $60 \%$. Os grupos informais caíram de $36 \%$ para 30,5\%, mostrando uma melhora na formalização dos empreendimentos. Já as cooperativas somam $8,8 \%$ do total e as diversas formas de sociedade mercantil, 0,6\% (Senaes, 2013). 
faz com que a empresa nasça com uma estrutura de capital deficiente e que freqüentemente a necessidade de capital de giro seja superior à sua capacidade de financiá-lo (TAUILE; DEBACO, 2002, p.3 Apud IASKIO, 2006, p 133).

A dificuldade de obtenção de capital de giro também foi identificada nos estudos de Pamplona (2009, p.80), que, ao consultar dados nacionais do primeiro mapeamento da Economia Solidária, conclui que,

quanto às dificuldades na comercialização, 33\% apontam a falta de capital de giro como um problema, enquanto para $29 \%$ dos EES a logística de armazenagem e distribuição é o principal gargalo.[...] Em relação ao crédito, apenas 16\% dos empreendimentos tiveram acesso a crédito (valor médio de cerca de $R \$ 100 \mathrm{mil}$ ), enquanto $52 \%$ buscaram e não tiveram acesso e $32 \%$ sequer procuraram obter financiamento. As principais dificuldades apontadas para a obtenção de crédito foram: falta de apoio técnico para elaboração de planos de negócio e projetos (36\%); não atendimento às condições relativas a garantias (31\%); taxas incompatíveis com a capacidade de pagamento (31\%); e dificuldade de obtenção da documentação exigida (29\%).

Todavia, as dificuldades que envolvem o financiamento de atividades dos empreendimentos solidários não se superam simplesmente com acesso ao sistema financeiro tradicional, pois as questões que afetam a disponibilidade de crédito a esses empreendimentos são também culturais ${ }^{18}$.

18 Segundo Abramovay (2004), as finanças informais não são um puro meio de troca, pois elas representam os próprios laços sociais existentes nas vidas dos indivíduos. Dessa forma, os pobres (que caracterizam o universo de trabalhadores de empreendimentos populares) tendem a substituir as fontes seguras de garantias (bens como imóveis, veículos, títulos, etc..) e fontes comprováveis de renda pela confiança pessoal com pessoas as quais eles transacionam. Singer (2004) afirma que os pobres pegam empréstimos de fornecedores, usuários, eventualmente de entidades de microcrédito e fundos consorciados, dos quais a cooperativa de crédito é a mais evoluída.

A cooperativa de crédito passa a ser a forma ideal para transacionar recursos com empreendimentos solidários, entretanto "o quadro de sócios duma cooperativa de crédito comunitária tem de ser constituído por produtores estabelecidos, em faixas de renda próximas, para que laços de confiança e solidariedade possa se desenvolver" (SINGER, 2004, p.15). Em outras palavras, é necessário que os trabalhadores, na lógica 
Uma forma dos empreendimentos econômicos solidários da Ameosc e da Amosc acessarem recursos têm sido justamente por meio de projetos propriamente elaborados ou com apoio das instituições. Entretanto, essa forma de captação ainda está longe de ser uma fonte garantidora da obtenção de recursos. Na Amosc o acesso ao crédito e financiamento por parte dos Empreendimentos Solidários é dificultado pela falta de formalização jurídica, além da ausência de informação sobre o acesso ao crédito e às fontes de financiamento. Na Ameosc, os recursos destinados para iniciar as atividades desses empreendimentos, em sua grande maioria, foram provenientes dos próprios sócios. Dos 12 empreendimentos que responderam sobre essa questão, 10 deles utilizaram recursos próprios para isso e dois obtiveram financiamentos: um a fundo perdido e o outro por meio de taxas de juros subsidiados.

Dos 11 empreendimentos que informaram sobre a atual necessidade de investimentos, seis afirmaram possuir tal necessidade, ou seja, mais da metade precisa captar recursos de fontes externas. Outra questão pontuada - que justifica o acesso a financiamento - diz respeito à urgência de construírem sedes próprias. Dos 14 EESs respondentes desta questão, cinco possuem sede própria, oito estão funcionando em unidades cedidas ou alugadas e apenas um não possui unidade alguma para seu funcionamento.

O fato de não ter uma sede própria pode impactar na comercialização dos produtos e na oferta de serviços, passando pela dificuldade de captação de recursos e, até mesmo, influenciando no aumento do número de sócios. Ainda, em relação às dificuldades geradas por não ter uma sede própria está a impossibilidade de captar recursos via projetos.

A preocupação com o êxodo rural nos empreendimentos da Ameosc, inclusive interferindo na perspectiva de continuidade de suas atividades, pode ser observada na fala de E.F., de Palma Sola: "para se ter uma ideia, tínhamos há 15 anos 48 sócios, agora tem 11 [...] eu acho que tinha que se dar mais incentivo para o colono, para a juventude ficar no campo [...]". Nessa direção, as consequências e também os desafios se expressam no depoimento de V. T., também de Palma Sola: "[...] o campo está envelhecendo, não sei se daqui um tempo continua

da Economia Solidária, se auto-organizem em cooperativas de crédito visando acessar maiores recursos e melhores tecnologias. 
[..], vai ser difícil! Se a juventude não colocar na cabeça que isso é bom, pode até acabar [...]. Vai faltar mão de obra no campo".

As dificuldades dos Empreendimentos Solidários não se restringem às questões relacionadas à formalização jurídica, comercialização, acesso a financiamentos e ao êxodo rural. Outros elementos são apontados nessa direção: a diferenciação de produtos; a falta de escala e sazonalidade; a falta de logística; e a dificuldade de trabalhar de modo autogestionário e associado.

$\mathrm{Na}$ região da Ameosc, há dificuldades de empreender trabalhos autogestionários e associados, ao considerar a participação de associados em espaços externos de comercialização e a integração para avançar no espírito e no trabalho associativo. Alguns empreendimentos avançaram nesse sentido, beneficiando-se do trabalho autogestionário tanto em relações estabelecidas como de confiança no produto comercializado.

Os benefícios da autogestão e da Economia Solidária vão além das relações sociais e institucionais estabelecidas. Há uma preocupação com o meio ambiente, sinalizando para uma alternativa ao desenvolvimento sustentável, que não está separado dos processos produtivos. Percebese uma opção tanto da Economia Solidária como da agricultura familiar pelos modos naturais (orgânicos) de produção, contrapondo a vertente agroindustrial, cujo foco é a alta produtividade e o baixo custo sem a preocupação de garantir alimentos saudáveis e ambientes sustentáveis.

A Economia Solidária aponta para uma nova forma de desenvolvimento, com valores e posturas práticas de cooperação, assentando-se como uma estratégia de inserção sócio-produtiva. As perspectivas da Economia Solidária na região oeste catarinense, delimitada nas microrregiões da Ameosc e Amosc, constituem-se num fenômeno com potencial de ampliação dos empreendimentos solidários como gerador de trabalho e renda e como dinamizador dos processos de desenvolvimento local, regional e sustentável ao promover processos de inclusão sócio-produtivos, envolvendo indivíduos e famílias trabalhadoras.

\section{CONSIDERAÇÕES FINAIS}


As ações da Economia Solidária e suas perspectivas na região oeste catarinense, delimitada nas microrregiões da Ameosc e Amosc, firmam-se com potencial de ampliação dos empreendimentos solidários, geradores de trabalho e renda e dinamizadores dos processos de desenvolvimento, envolvendo indivíduos e famílias trabalhadoras.

Não obstante, há que se considerar os limites que esses empreendimentos vêm enfrentando, em especial, no que tange à mobilização e articulação política e à qualificação profissional, técnica e gerencial. Desse modo, faz-se necessário investir para ampliar tanto a participação dos associados quanto a adesão da comunidade local nas discussões em torno da Economia Solidária e em novas apostas de criação de empreendimentos dessa natureza.

$\mathrm{Na}$ realidade estudada há que se considerar também que as instituições apoiadoras de empreendimentos solidários são diversas no âmbito da esfera governamental e não governamental, proporcionando acessos à infraestrutura e orientações técnico-gerenciais e políticas e de qualificação profissional. Contudo, um dos grandes desafios no campo da Economia Solidária perpassa pela falta de formalização jurídica dos empreendimentos, o que impede muitos deles de vender em âmbito estadual, que uma vez superada poderia dirimir dificuldades de comercialização dos produtos.

Em síntese, a Economia Solidária se destaca como alternativa ao enfrentamento dos problemas gerados pelo sistema capitalista, que de modo massivo, tem provocado acentuados processos de desigualdade e exclusão social e de exploração nas relações de trabalho. Nesse sentido, a Economia Solidária abre oportunidades de inclusão sócio-produtiva e (re)valorização de outras dimensões além da econômica, como a criatividade, as relações sociais solidárias, culturais e políticas entre trabalhadores.

A realidade estudada revela que há avanços de ordem política e de gestão implicados nas ações de Economia Solidária desenvolvidas na região oeste catarinense. Aliado a esses avanços, há desafios que carecem ser enfrentados a curto e médio prazos no sentido de aprimorar a "educação para Economia Solidária", junto dos associados e das comunidades locais. Consolidar os EESs como unidades de trabalho 
sócio-produtivo permite gerar processos de participação, autogestão e de desenvolvimento regional mais igualitário e sustentável.

\section{REFERÊNCIAS}

ABRAMOVAY, Ricardo. Laços Financeiros na Luta contra a Pobreza. São Paulo: Annablume; Fapesp; ADS-CUT; Sebrae, 2004.

AMEOSC, Associação de Municípios do Extremo Oeste de Santa Catarina. O Desenvolvimento Associativo. 2013. Disponível em:

<http://www.ameosc.org.br/municipios/index.php\#>. Acesso em: 12 jul. 2013.

AMOSC, Associação de Municípios do Oeste de Santa Catarina. AMOSC Aspectos Institucionais. 2013. Disponível em:

<http://www.amosc.org.br/conteudo/?item $=1794 \&$ fa $=251$ \&PHPSESSID $=$ gc703hks405Inn00inds 1q40c3 $>$. Acesso em 25 ago. 2013.

CUNHA, Gabriela Cavalcanti. A construção da rede de políticas públicas de Economia Solidária no governo federal: notas de pesquisa. In: BENINI, Édi...[et al]. Gestão Pública e Sociedade: fundamentos e políticas públicas de economia solidária. São Paulo: Outras expressões, 2012.

FBES, Fórum Brasileiro de Economia Solidária. Lançamento do Documento Final da V Plenária Nacional de Economia Solidária. 2013. Disponível em: $<$ http://www.fbes.org.br/index.php?ption=com_content\&task=view\&id $=7611$ \&ltemid $=62$. $>$ Acesso em 22 set. 2013 .

FECAM, Federação Catarinense de Municípios. Guia do Municípios Catarinenses. Disponível em $<$ http://guia.fecam.org.br/associacoes/index.php> Acesso em abr. 2012

FIORENTIN, Marcos. Uma perspectiva de Território Integrado no Consad Extremo Oeste de Santa Catarina. 2012. Tese apresentada ao Programa de Pós-graduação em Geografia como requisito para obtenção do título 
de Doutor em Geografia. Universidade Federal do Rio Grande do Sul, 2012.

FRANÇA FILHO, Genauto Carvalho de. Teoria e prática em economia solidária: problemática, desafios e vocação. Porto Alegre. Civitas Revista de Ciências Sociais, v. 7, n. 1, jan.-jun. 2007.

GRANOVETTER, M. The strength of weak ties. In: American Journal of Sociology, 78 (6), p.1360-1380, 1973.

IASKIO, Emerson Leonardo Schmidt. A Economia Solidária Diante da Concorrência capitalista: Os Limites Econômicos Da Autogestão. Revista Emancipação 6(1): 119-143, 2006.

MARQUES, Valesca Menezes; DIAS, Leila Christina. Associações de municípios em Santa Catarina: da gênese à consolidação. Geosul, Florianópolis, v. 18, n. 36, p 29-53, jul./dez. 2003. Disponível em: <https://periodicos.ufsc.br/index.php/geosul/article/view/13576.> Acesso em: 12 ago. 2013.

PAMPLONA, Leonardo. Políticas Públicas de Geração de Trabalho e Renda: O desafio da Atuação do BNDES na Economia Solidária. BNDES Setorial Ed.30, p. 63 - 102, 2009.

PITAGUARI, Sinival Osório. A Economia Solidária no Brasil: Políticas Públicas e Desenvolvimento Local. 2010. 145f. Dissertação (Curso de Mestrado em Economia Regional) - Universidade Estadual de Londrina, Londrina, 2010.

POLI, Odilon Luiz. Economia solidária e formação humana: experiências de trabalho e educação em agroindústrias familiares associativas no Oeste catarinense. 2006. 353f. Tese de Doutorado (Programa de PósGraduação em Educação) - Universidade Estadual de Campinas, Campinas, 2006.

SANCHEZ, Fábio José Bechara. A luta pelo direito ao trabalho associado: apontamentos sobre o marco jurídico da Economia Solidária. 2012. In: 
BENINI, Édi...[et al]. Gestão Pública e Sociedade: fundamentos e políticas públicas de economia solidária. São Paulo: Outras expressões, 2012.

SANTOS, Aline Sueli de Salles. Economia Solidária: formas jurídicas e licitações públicas. 2012. In: BENINI, Édi...[et al]. Gestão Pública e Sociedade: fundamentos e políticas públicas de economia solidária. São Paulo: Outras expressões, 2012.

SENAES/MTE. Secretaria Nacional de Economia Solidária / Ministério do Trabalho e emprego. Atlas da Economia Solidária no Brasil 2005-2007. 2007. Disponível em <http://consulta.mte.gov.br/atlas/AtlasES.html> Acesso em 07 fev. 2010.

SENAES, Secretaria Nacional de Economia Solidária. Sistema Nacional De Informações De Economia Solidária -Sies - Disponibiliza Nova Base De Dados. Boletim Informativo. Ano V. Edição Especial: Divulgação do dados do SIES 2013. 2013. Disponível em:

<http:/ / portal.mte.gov.br/data/files / 8A7C816A416FABB60141 73C4E66 C7839/Acontece\%20SENAES\%202013\%20\%20n34\%20ed\%20espercial.Pdf.> Acesso em 12 nov. 2013

SIES, Sistema Nacional de Informações de Economia Solidária. Base de Dados 2010-2012. Versão 2013. Dados fornecidos em Copy DisK (CD) pela Secretaria Nacional de Economia Solidária. 1 CD-ROM.

SINGER, Paul. Introdução à Economia Solidária. São Paulo, fundação Perseu Abramo, 2002.

Apresentação. 2004. In: ABRAMOVAY, Ricardo. Laços Financeiros na Luta contra a Pobreza. São Paulo: Annablume; Fapesp; ADS-CUT; Sebrae, 2004

SIMIONATTO, I. Estado e sociedade civil em tempos de globalização: reinvenção da política ou despolitização? In: Cadernos Especiais n. 39, edição: 23 de outubro a 20 de novembro de 2006. Disponível em: $<$ www.assistentesocial.com.br. $>$ Acesso em 10 out. 2013. 
UNOCHAPECÓ, Universidade Comunitária Regional de Chapecó. Catálogo dos Empreendimentos Econômicos Solidários no Estado de Santa Catarina. Chapecó, 2007

VALENTIM JR, Sérgio Luiz; SOBOTTKA, Emil Albert. O Movimento da Economia Solidária: a emergência de um movimento social pela humanidade. Programa de Pós-Graduação em Ciências Sociais da Faculdade de Filosofia e Ciências Humanas da Pontifícia Universidade Católica do Rio Grande do Sul - PUCR. III Mostra de Pesquisa da PósGraduação - PUCRS, 2008.

YIN, Robert K. Estudo de Caso: planejamento e método. Trad. Daniel Grassi. - 3.ed.- Porto Alegre: Bookman, 2005.

Submetido em 10/08/2014.

Aprovado em $21 / 10 / 2015$.

\section{Sobre os autores}

Luiz Victor Pittella Siqueira

Mestre em Políticas Sociais e Dinâmicas Regionais. Diretor de Planejamento da Universidade

Federal da Fronteira Sul - UFFS.

Endereço: Rua Mato Grosso 600-D, apto. 401-A, Jardim Itália. 89.802-271 - Chapecó, SC, Brasil.

E-mail:victor@uffs.edu.br

\section{Dunia Comerlatto}

Doutora em Serviço Social. Professora na Universidade Comunitária da Região de Chapecó - Unochapecó.

Endereço: Rua Florianópolis, 100-E, apto 201, Centro. 89.812-120 - Chapecó, SC, Brasil.

E-mail:dunia@unochapeco.edu.br

\section{Jésica Mai}

Bacharel em Serviço Social pela Universidade Comunitária da Região de Chapecó Unochapecó.

Endereço: Rua Porto União, 555, Centro. 89.883-000 - Águas de Chapecó, SC, Brasil. E-mail: jesicamai@unochapeco.edu.br 